\title{
O REINO E O DESERTO \\ A INQUIETANTE MEDIEVALIDADE DO MODERNO
}

\author{
Eduardo Sterzi \\ Universidade Estadual de Campinas
}

O ano é 1947, e João Cabral de Melo Neto, que havia pouco assumira o posto de vice-cônsul em Barcelona, imprime ele próprio, na prensa manual que comprara naquele mesmo ano por razões terapêuticas, seu quarto livro, com o longo título encadeado de Psicologia da composição com a Fábula de Anfion e Antiode. ${ }^{1} \mathrm{O}$ volume, como seu título permite depreender, traz três poemas. O primeiro, «Fábula de Anfion», embora retome uma linha de reflexão sobre a poesia já delineada no livro imediatamente anterior, $O$ engenheiro ${ }^{2}$, e que estará também no centro dos dois outros poemas agora publicados, «Psicologia da composição» e «Antiode (contra a poesia dita profunda)», deixa no leitor familiarizado com o conjunto da obra cabralina uma persistente sensação de estranheza. Antes de mais nada, porque se trata, salvo engano, do único poema de Cabral que se organiza a partir de uma explícita referência mitológica, inscrita já no título. Tal referência não lhe chegava diretamente do manancial grego-antigo, mas, sim, por intermédio de um autor cujos ensaios ele vinha lendo com atenção desde a adolescência e ao qual já homenageara dedicando-lhe um poema, Paul Valéry. ${ }^{3}$

Em 23 de junho de 1931, estreara, na Ópera de Paris, o «melodrama» Amphion, escrito por Valéry e musicado por Arthur Honegger. O poema - introduzido, agora, pelo texto da conferência «Histoire d'Amphion», proferida em janeiro do ano seguinte - foi recolhido em Varieté III, de 1936, livro em que Cabral o leu. ${ }^{4}$ Em seu «melodrama»-

\footnotetext{
${ }^{1}$ João Cabral de Melo Neto, Psicologia da composição com a Fábula de Anfion e Antiode, Barcelona: O Livro Inconsútil, 1947. O livro será citado aqui a partir da sua republicação na Obra completa de Cabral, org. Marly de Oliveira com assistência do autor, Rio de Janeiro: Nova Aguilar, 1994, pp. 85-102. Sobre os motivos terapêuticos do trabalho na prensa manual, cf. João Cabral de Melo Neto, carta a Manuel Bandeira datada de 4 de setembro de 1947, em Correspondência de Cabral com Bandeira e Drummond, org., apres. e notas Flora Süssekind, Rio de Janeiro: Nova Fronteira e Casa de Rui Barbosa, 2001, p. 32, e carta a Carlos Drummond de Andrade, id., p. 220. Sobre a impressão de Psicologia da composição..., cf. carta sem data de Cabral a Bandeira, id., p. 52.

2 Vejam-se, sobretudo, «O poema», «A lição de poesia» e «Pequena ode mineral», em que esta reflexão sobre a poesia é explicitamente enunciada; mas não se esqueçam poemas como «A paisagem zero», «O engenheiro», "A estações», "A mesa», «O fantasma na praia», "O funcionário», para não falar das composições dedicadas desde seus títulos a outros poetas (Carlos Drummond de Andrade, Joaquim Cardozo, Paul Valéry), a um pintor (Vicente do Rego Monteiro) e mesmo a um jogador de futebol (Newton Cardoso), em que tal reflexão é formulada de modo mais oblíquo. Cf. João Cabral de Melo Neto, $O$ engenheiro, em Obra completa cit., pp. 65-84.

3 Cf. José Castello, João Cabral de Melo Neto. O homem sem alma, Rio de Janeiro: Rocco, 1996, pp. 47-48 e 51 («De Valéry, ele lê os ensaios, não os versos, que não o interessam»). João Cabral de Melo Neto, «A Paul Valéry», O engenheiro, em Obra completa cit., pp. 82-83.

4 Paul Valéry, «Histoire d'Amphion» (1932) e «Amphion (mélodrame)» (1931), em V arieté III, IV et V, Paris: Gallimard, 2002, pp. 83-93 e 95-115. Amphion também se encontra publicado entre as Poésies da edição
} 
«nem uma ópera, nem um balé, nem um oratório» ${ }^{5}$-, Valéry retornava a «esses gregos que tudo viram» (ces Grecs qui ont tout vu) para tomar-lhes emprestado não só o personagem mítico que converteu em seu protagonista, mas, sobretudo, para solicitar-lhes o poder poder «antigo» por excelência - de dar corpo às idéias através dos mitos: «Nossas idéias não têm corpo. Nós pensamos por esqueletos. Nós perdemos a grande arte de significar pela beleza». ${ }^{6}$ Uma convocação dos «antigos» (anciens), de seus mitos e métodos - uma invocação, em suma, da Antigüidade - está na origem, portanto, do poema. Mas o poema não se esgota nessa invocação. A preocupação que o atravessa, embora reminiscente da reflexão grega, é fundamentalmente moderna: trata-se de discernir e figurar o princípio arquitetônico (ou, mais precisamente, arquitetônico-musical) que está - ou, ao menos para Valéry, deveria estar - no centro de toda produção artística, incluindo-se aí a poesia, como o seu «momento mais puro» ${ }^{7}$, momento apolíneo de pura «construção» (definida como «a passagem da desordem à ordem», como «uso do arbitrário para atingir a necessidade»), de pura «forma» (ou «estrutura»), para além da «imitação das coisas». ${ }^{8} \mathrm{Em}$ certa medida, parece ter sido esta também a preocupação inicial de Cabral na «Fábula de Anfion», mas com diferenças significativas na figuração do tema.

A primeira divergência concerne à paisagem em que se desenrola a história de Anfion. Na rubrica inicial de seu «melodrama», Valéry determina que, no palco, se deve divisar «uma brecha ou fenda imensa na rocha do topo de uma montanha», deixando entrever, no intervalo que se abre do piso ao teto, o «céu» recortado; no plano inferior das duas massas rochosas, há «árvores poderosas [arbres puissantes], carvalhos, faias, castanheiras»; no centro do cenário, «uma poça ou fonte de água sombria», em torno da qual se verifica uma «desordem» de «blocos de granito ou de basalto», os quais, ao fundo, quase fecham a fenda; somente mais acima aparece «a região mineral nua»; próximo do cume da massa da direita, insinuam-se «formas cristalinas, feixes de prismas emaranhados [faisceaux de prismes enchevêtrés]», com «algumas facetas [...] vagamente luminosas»;

ampliada de 1958 (houve uma anterior, de 1929). Sobre a leitura dos cinco tomos de Varieté por Cabral, cf. José Castello, João Cabral de Melo Neto cit., p. 51. Para a leitura da «Fábula de Anfion» a partir de sua relação com o poema de Valéry, cf. Luiz Costa Lima, Lira e antilira. Mário, Drummond, Cabral (1968), $2^{a}$ ed. revista, Rio de Janeiro: Topbooks, 1995, pp. 229-233; Eucanaã Ferraz, «Anfion, arquiteto», em Paisagem tipográfica. Homenagem a João Cabral de Melo Neto (1920-1999), Colóquio/Letras, 157-158 (jul.-dez. 2000), pp. 81-98 (mas especialmente pp. 81-82).

5 Paul Valéry, «Histoire d'Amphion» cit., p. 92.

${ }^{6}$ Idem, p. 88.

7 Paul Valéry, «Amphion (mélodrame)» cit, p. 104.

8 Paul Valéry, «Histoire d'Amphion» cit., pp. 85 e 87. 
pontilhando as alturas, o brilho de «um pouco de neve». ${ }^{9}$ Quando Anfion entra no palco, não está sozinho:

Ao levantar-se a cortina, criaturas noturnas dançam em pequenos grupos, em diversos pontos da paisagem. Elas desaparecem, não permanecendo visíveis senão o tempo de serem percebidas nas trevas transparentes.

Entram pela direita e pela esquerda homens e mulheres que se buscam, se falam por sinais, se dispõem sob as árvores. Eles se preparam para o repouso, reingressando logo nas sombras das coxias.

Entende-se na calma a Harmonia das Esferas. ${ }^{10}$

Em resumo, Valéry coloca seu espectador diante de uma paisagem que poderia ser definida como uma quase paradoxal versão escarpada do locus amœnus da tradição clássica $^{11}$, na qual Amphion tem a companhia de seres humanos e sobre-humanos. Paisagem propícia para a encenação do embate entre criação e caos, entre os «atos puros» de Anfion e a «desordem das rochas» ${ }^{12}$ : a natureza primigênia aparece, no poema, como o resultado de uma destruição imemorial, de uma destruição originária; armado da lira que Apolo lhe deu, Amphion vale-se da música para «excitar» a «natureza» ${ }^{13}$, a tal ponto que as pedras passam a mover-se por si mesmas, encontrando cada uma o seu lugar apropriado na edificação do Templo dedicado ao deus. O Templo se ergue, sem esforço, em oposição ao «caos» das «ruínas dos montes» (expressão que, significativamente sintomaticamente -, aparece duas vezes no poema de Valéry). ${ }^{14}$ É preciso submeter a natureza - a «terra» - pelo encantamento divino. ${ }^{15} \mathrm{O}$ próprio Amphion, consciente da violência que a imposição de ordem implica, se pergunta: «Terei ferido, chocado, / Encantado, talvez, / O Corpo secreto do mundo?»» ${ }^{16}$ Construído o Templo, Amphion é proclamado «pontífice» e «Rei» pelo «coro do povo». Porém, logo depois da investidura, enquanto se dirige ao trono, seu percurso é interrompido por uma figura feminina que, oculta atrás de um véu, o envolve com ternura, o destitui da lira e a lança à água: «figura que», conforme explica Valéry, «é o Amor ou a Morte». ${ }^{17}$

São bastante diversas a paisagem e a correspondente situação em que Cabral apresenta seu Anfion. Encontra-se ele sozinho no deserto, e sozinho permanecerá mesmo

\footnotetext{
${ }_{9}^{9}$ Paul Valéry, «Amphion (mélodrame)» cit., p. 97.

${ }^{10}$ Id., pp. 97-98.

11 Cf. Ernst Robert Curtius, «A paisagem ideal», em Literatura européia e Idade Média latina, trad. Teodoro Cabral e Paulo Rónai, São Paulo: Hucitec e Edusp, 1996, pp. 241-261 (mas especialmente pp. 254-258).

12 Paul Valéry, «Amphion (mélodrame)» cit., p. 110.

${ }^{13}$ Id., p. 105: «Arme-toi de la Lyre! Excite la nature!».

${ }^{14} I d$., pp. 105 e 110.

15 Id., p. 112: «Ô Miracle! Ô Merveille! / Le roc marche! la terre est soumise à ce dieu, / Quelle vie effrayante envahit la nature? / Tout s'ébranle, tout cherche l'ordre, / Tout se sent un destin!».

${ }^{16}$ Id., p. 110: «Ai-je blessé, heurté, / Charmé, peut-être, / Le Corps secret du monde?».

${ }^{17}$ Id., p. 115.
} 
depois de fundar Tebas. «Ao invés da exuberância de um cenário ao mesmo tempo natural e sobrenatural, deparamos com a solidão absoluta numa cena inóspita e sem transcendência», observa Eucanaã Ferraz. ${ }^{18}$ Se Apolo, no poema de Valéry, já era apenas uma voz que se projetava sobre o palco para confiar sua lira - o instrumento ordenador a Anfion ${ }^{19}$, agora, no poema de Cabral, ele não aparece em forma alguma. Aliás, o instrumento que Anfion toca, na «Fábula», é outro: uma flauta. E dito com maior precisão: uma «flauta seca» (precisão com que Cabral parece querer conjurar - nos dois sentidos antitéticos do verbo: invocar e afastar - o deus tradicionalmente identificado com o instrumento, Pã, deus antiapolíneo por excelência desde a contenda musical arbitrada por Midas: deus do pânico, do desordenamento ${ }^{20}$ ). Na «Fábula» escrita por Cabral, Anfion já se encontra num tempo posterior aos deuses: a sua é já uma «condição póstuma» (condição própria da literatura, como sugere Giulio Ferroni ${ }^{21}$ ), permeada por um destino que se chama «acaso» - ao qual, mallarmeanamente, se dá combate, e que pode ser também um dos nomes secretos da História. História, por sinal, que, até este momento da obra cabralina, subsistia impronunciada, não-dita, ainda que, inevitavelmente, estivesse já aí presente.

Os «atos puros» do Amphion de Valéry se condensam aqui no «gesto puro / de resíduos» que o Anfion de Cabral executa «no deserto, entre a / paisagem de seu / vocabulário», «entre pedras» que são «como frutos esquecidos / que não quiseram // amadurecen»: «gesto puro» que consiste simplesmente em «respira[r] / o deserto», mas que é «como se preciso círculo / estivesse riscando // na areia». ${ }^{22}$ Anfion devolve o ar ao deserto por meio da «flauta seca». Instala-se assim uma singular reciprocidade, não encontrada em Valéry, entre paisagem e instrumento, ou, em outras palavras (levando-se em conta o caráter fundamentalmente metapoético da «Fábula», assim como dos outros dois poemas do livro), entre cenário e poema. A partir daqui, Cabral se esforça pela afirmação de uma verdadeira ética estética da aridez, que alcançará, talvez, seu ápice com $A$ educação pela pedra, de 1966. A «esterilidade» (expressão que aparece à margem do poema, anotada pelo próprio Cabral) não é apenas a situação contingente com que Anfion se depara ao chegar ao deserto e que deveria enfrentar, mas é também sua meta. «Sua mudez

\footnotetext{
${ }^{18}$ Eucanaã Ferraz, «Anfion, arquiteto» cit., p. 82.

${ }_{19}$ Cf. Paul Valéry, «Amphion (mélodrame)» cit., pp. 104-105 (é Apolo quem fala a Anfion): «Je place en toi l'origine de l'ordre, / J'habiterai ton moment de plus pur, / Et désormais s'accompliront / Sur la face de la terre / Des actes vénérables / Où paraîtra la céleste sagesse! / Je te confie l'invention d’Hermès! / Je te remets l'arme prodigieuse, / La Lyre!».

${ }^{20} \mathrm{E}$ isto ao mesmo tempo que Cabral registra sua conhecida aversão à música

${ }^{21}$ Cf. Giulio Ferroni, Dopo la fine. Sulla condizione postuma della letteratura, Torino: Einaudi, 1996.

${ }^{22}$ João Cabral de Melo Neto, «Fábula de Anfion» cit., p. 87.
} 
está assegurada / se a flauta seca», pensa Anfion. E - por esta secura, por esta mudez - a história-acaso lhe parece dominada:

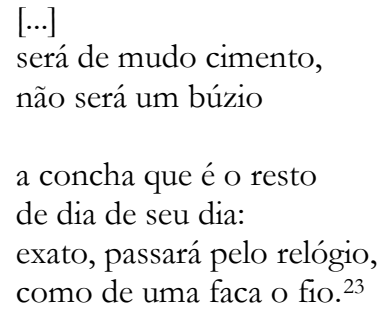

Mas o acaso espreita Anfion no deserto e comporta um hino de assombro e reconhecimento do poder:

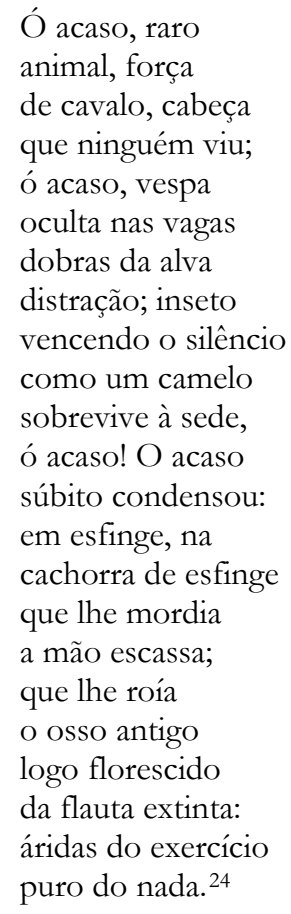

Ao soar, frente ao acaso, a «flauta seca» de Anfion, «Tebas se faz». E é muito significativo, quanto à perspectiva pela qual Cabral observa a história, que o «aéreo / parto» da cidade - que é, por isso, definida «milagre» - seja figurado como um desdobramento do tempo em outro tempo:

Quando a flauta soou um tempo se desdobrou do tempo, como uma caixa de dentro de outra caixa. ${ }^{25}$

\footnotetext{
${ }^{23} I d$., p. 89.

${ }^{24} I d$., pp. 89-90.

25 Id., p. 90.
} 
É a propósito da irrupção deste outro tempo - o tempo propriamente histórico, para além do «milagre» - que sempre nos disse e «diz a mitologia» por meio de seus «nítidos enigmas». ${ }^{26}$ Daí que Cabral, na «Fábula», recorra ao mito, ainda que seja por uma única vez em toda sua obra: se, por um lado, conforme argumentaram filósofos como Walter Benjamin e Giorgio Agamben, a história emerge da origem (da Ursprung) e permanece numa constante dialética com $\operatorname{esta}^{27}$, e se, por outro, a função básica da mitologia parece ter sido sempre a de figurar a origem - não como momento cronologicamente prévio à história, mas como tempo desdobrado, contíguo ao tempo histórico e que de forma pontual, ao modo de um relâmpago, interfere neste ${ }^{28}$-, é compreensível que Cabral encene o drama mítico de Anfion justo às vésperas de passar da poética pré-histórica (ou originária) de seus primeiros poemas (em que o tempo e o espaço eram indeterminados) a uma poética resolutamente histórica (em que as marcações temporais e geográficas serão abundantes, a começar pelo livro imediatamente seguinte, $O$ cão sem plumas, em que o rio Capibaribe é nomeado sem rodeios). É também compreensível que, precisamente neste momento em que sua primeira poesia chegava a um ponto de impasse (e impasse sentido como tão grave que Cabral pensou em abandonar a poesia ${ }^{29}$ ), ele apresente Anfion como um construtor arrependido, saudoso do deserto inicial. O personagem lamenta-se perante a «injusta sintaxe / que fundou», contemplando Tebas «como / a um tecido que // buscasse adivinhar / pelo avesso», em busca do deserto ali talvez ainda latente:

\footnotetext{
Esta cidade, Tebas, não a quisera assim de tijolos plantada,

que a terra e a flora
}

\footnotetext{
${ }^{26}$ Id., p. 90.

${ }^{27}$ Walter Benjamin, Origem do drama trágico alemão, trad. João Barrento, Lisboa: Assírio \& Alvim, 2004, p. 32; Giorgio Agamben, Infanz̧ia e storia. Distruz̧ione dell'esperienza e origine della storia (1978), nuova edizione accresciuta, Torino: Einaudi, 2001; id., Il tempo che resta. Un commento alla Lettera ai Romani, Torino: Bollati Boringhieri, 2000; id., «Archeologia filosofica», em Signatura rerum. Sul metodo, Torino: Bollati Boringhieri, 2008, pp. 82-111.

$28 \mathrm{O}$ mito não somente conta como «uma realidade veio à existência», não somente relata «como alguma coisa foi produzida, começou a sen» (Mircea Eliade, Aspects du mythe, Paris: Gallimard, 1996, pp. 16-17), mas também registra suas possibilidades de extinção, que também são parte da origem tal como considerada por Benjamin (“"Origem” não designa o processo de devir de algo que nasceu, mas antes aquilo que emerge do processo de devir e desaparecer. [...] Em todo fenômeno originário tem lugar a determinação da figura através da qual uma idéia permanentemente se confronta com o mundo histórico, até atingir a completude na totalidade da sua história.» Origem do drama trágico alemão cit., p. 32). João Cabral, na «Fábula de Anfion», alude a essa persistência dos mitos representando-os como «mariscos / ou simples nozes / cuja noite guardada / à luz e ao ar livre / persiste, sem se dissolver» (p. 90).

${ }^{29}$ Cf. João Cabral de Melo Neto, carta a Manuel Bandeira sem data, em Correspondência de Cabral com Bandeira e Drummond cit., p. 68; José Castello, João Cabral de Melo Neto. O bomem sem alma, Rio de Janeiro: Rocco, 1996, pp. 95 e 100.
} 


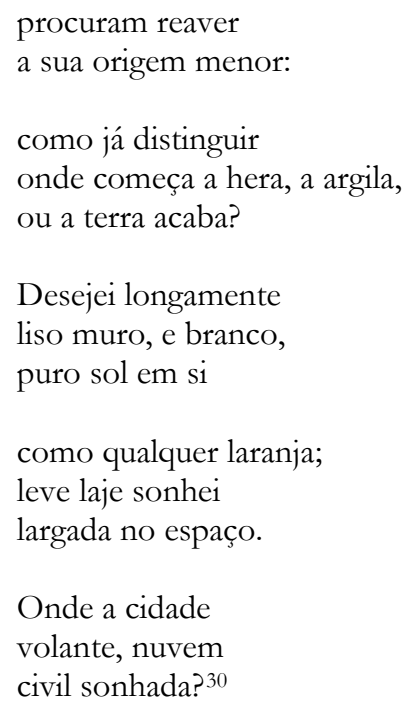

O arrependimento com a cidade fundada - inevitavelmente desordenada, sempre prestes a retornar ao caos primevo, se comparada seja com o deserto, seja com a cidade ideada - leva Anfion a abandonar sua flauta, lançada ao mar (assim como fora lançada à fonte a lira do Amphion de Valéry; mas, em Cabral, como bem observou João Alexandre Barbosa, a ação é do herói, que toma para si a determinação do seu destino, e não um efeito do Amor ou da Morte ${ }^{31}$ ):

\author{
Uma flauta: como \\ dominá-la, cavalo \\ solto, que é louco? \\ Como antecipar \\ a árvore de som \\ de tal semente? \\ daquele grão de vento \\ recebido no açude \\ a flauta cana ainda? \\ Uma flauta: como prever \\ suas modulações, \\ cavalo solto e louco? \\ Como traçar suas ondas \\ antecipadamente, como faz, \\ no tempo, o mar? \\ A flauta, eu a joguei \\ aos peixes surdos- \\ mudos do mar. ${ }^{32}$
}

\footnotetext{
30 João Cabral de Melo Neto, «Fábula de Anfion» cit., pp. 91-92.

31 João Alexandre Barbosa, A imitação da forma. Uma leitura de João Cabral de Melo Neto, São Paulo: Duas Cidades, 1975, p. 69.

32 João Cabral de Melo Neto, «Fábula de Anfion» cit., p. 92.
} 
Se, na «Fábula de Anfion», Cabral, através deste abandono final da flauta, representa o momento estritamente negativo de sua poética, momento em que o impasse parece não ter solução, em outro poema do mesmo livro, aquele que dá título ao conjunto, «Psicologia da composição», a negatividade é de tal modo assumida que se torna, dialeticamente, o objetivo a atingir:

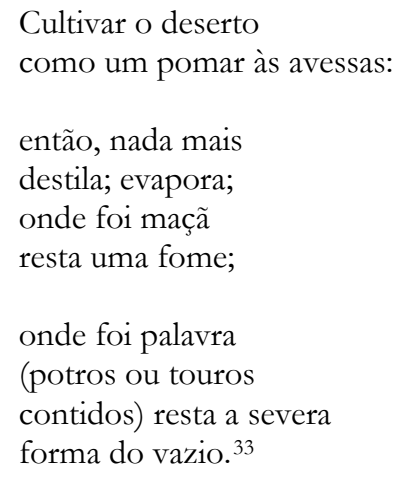

$\mathrm{O}$ «deserto» torna-se, agora, interno ao texto: ele se condensa na «severa forma do vazio» a ser perseguida pelo poeta. Curiosamente, essa perseguição, nos anos seguintes à publicação de Psicologia da composição com a Fábula de Anfion e Antiode, esteve menos a cargo do próprio Cabral do que de um poeta que, desde o princípio de sua trajetória, se reconheceu, como escreveria décadas depois, seu «aprendiz». ${ }^{34}$

O ano, agora, é 1951, e Augusto de Campos, então um jovem poeta à entrada dos seus vinte anos, publica seu primeiro livro, $O$ rei menos o reino, pelo fugaz selo Edições Maldoror, atrás do qual mal se ocultava a impressão às expensas do autor. ${ }^{35}$ Reuniam-se no volume poemas escritos desde 1949. Uma primeira epígrafe introduzia o conjunto todo ali encadernado - um verso bastante conhecido do canto terceiro do Inferno de Dante: «Queste parole di colore oscuro...». Ultrapassando-se um poema introdutório grafado em itálico (posteriormente excluído das reedições de $O$ rei menos o reino no quadro da poesia coligida do autor ${ }^{36}$ ), chega-se ao poema que empresta seu título ao livro,

33 João Cabral de Melo Neto, «Psicologia da composição», em Obra completa cit., p. 97.

34 Augusto de Campos, «a joão cabral: agrestes» (1985), em O anticrítico, São Paulo: Companhia das Letras, 1986, p. 11; depois, com título modificado, «joão/agrestes», em despoesia, São Paulo: Perspectiva, 1994, p. 77. 35 Augusto de Campos, O rei menos o reino. 1949-1951, São Paulo: Maldoror, 1951.

36 Augusto de Campos, Viva vaia. Poesia 1949-1979, São Paulo: Duas Cidades, 1979; $2^{a}$ ed., São Paulo: Brasiliense, 1986; $3^{a}$ ed., Cotia: Ateliê, 2001. O livro será citado aqui a partir desta última edição, com correções baseadas na $2^{\text {a }}$. 
precedido por uma nova epígrafe, agora de Hölderlin, a célebre questão elaborada na elegia «Brot und Wein» («Pão e vinho»): «...und wozu Dichter in dürftiger Zeit?», na primeira edição ainda não acompanhada da tradução que Augusto providenciaria para as republicações - «...e para que poetas em tempo de pobreza?».

A seqüência das epígrafes não deixa dúvidas quanto às preocupações que estavam na base da poesia de Augusto de Campos por aquela época. Dito de modo sumário, tratava-se de conjugar uma questão de palavra com uma questão de tempo: o poema se apresentava, de uma só vez, como uma investigação da linguagem e como uma investigação da história. Mas também aqui essa dupla investigação elege como seu campo de provas aquela história originária (ou pré-história) já visada por Cabral na «Fábula de Anfion» - e, como naquele poema, é outra vez a história de um rei frente a um deserto que se conta. Agora, porém, não há mais o solo conhecido da mitologia grega para sustentar a leitura e a interpretação, e as imagens, bem mais abstratas ou dispersivas que as de Cabral, assim como o fraseado espiralado, que freqüentemente se volta sobre si mesmo e retarda o prosseguimento da exposição, impedem uma rápida ou completa decodificação. É, no entanto, também aqui, de um cultivo do deserto que se fala. E esse cultivo não se faz por meio dos sons da lira ou da flauta, mas, sim, por meio da voz que canta, ou que cantava e agora silencia:

Onde a Angústia roendo um não de pedra

Digere sem saber o braço esquerdo,

Me situo lavrando este deserto

De areia areia arena céu e areia.

Este é o reino do rei que não tem reino

E que - se algo o tocar - desfaz-se em pedra.

Esta é a pedra feroz que se faz gente

- Por milagre? de mão e palma e pele.

Este é o rei e este é o reino e eu sou ambos.

Soberano de mim: O-que-fui-feito,

Solitário sem sol ou solo em guerra

Comigo e contra mim e entre os meus dedos.

Por isso minha voz esconde outra

Que em suas dobras desenvolve outra

Onde em forma de som perdeu-se o Canto

Que eu sei aonde mas não ouço ouvir. ${ }^{37}$

A instabilidade semântica dos versos parece incorporar o contágio entre a paisagem e seu habitante que neles se representa: a negatividade do deserto passa para o rei, que, transmitindo-a para seu reino, elimina-o; em seu lugar, resta apenas o poema que se está

${ }^{37} I d .$, p. 9. 
lendo, o qual, exatamente porque, vez ou outra, parece girar em falso, como que circunscreve a «severa forma do vazio» a que aludia Cabral. «Este é o rei e este é o reino e eu sou ambos»: a vOz que aí se ouve parece ser menos do poeta ou do rei-personagem que do próprio poema, que se propõe como espaşo político.

Ao contrário de Anfion, que estava absolutamente sozinho, o rei está acompanhado, aqui, de vozes sem corpos (como incorpórea já era a voz de Apolo, no «Amphion» de Valéry):

\footnotetext{
Neste reino onde eu canto ao som de areia Às vezes o ar se move de outras vozes

Que - despidas dos corpos - se aproximam

Da minha voz se nunca do meu Canto. ${ }^{38}$
}

De quem são estas vozes? Em alguma medida, são as vozes da própria natureza sobrevivente, embora totalmente mineralizada, fundamentalmente inorgânica, por debaixo do deserto:

De sob a rocha escuto os finos rios
De mercúrio torcendo-se de frio
Até que em meu ouvir se precipitam. ${ }^{39}$

O que estas vozes pedem?
- Um sol, mesmo sem sangue, mas um sol
Mas que ilumine o olhar, mesmo sem brilho,
E a dura voz a dura dura voz
Dos corvos doure... (Aqui retorna o vento) ${ }^{40}$

O rei atende, e o que oferece é uma espécie de contrafação da «cidade volante», da «nuvem civil sonhada», do Anfion cabralino:

Vinde e vereis florir um sol no céu

E um céu se desdobrar do olhar do sol,

Neste reino onde o céu é o vosso ar alto,

Onde o sol é de pedra como o Canto. ${ }^{41}$

Aparece, então, no discurso do rei uma figura feminina que, como no melodrama de Valéry, se confunde com o Amor e a Morte. Aqui ela é feita rainha:

\footnotetext{
${ }^{38} I d$., p. 10.

${ }^{39}$ Id., ibid.

${ }^{40}$ Id., ibid.

${ }^{41}$ Id., ibid.
} 
Nesse reino

Onde eu sou o rei e és a morta rainha

Ou onde eu sou

O rei e és a rainha morta e a morte

São meus braços,

O referido reino onde os tristes vassalos

Nunca encontram o rei que em si mesmos procuram

E onde o rei se coroa à falta de vassalos

E onde à falta de reino pisa o próprio corpo

(Duro reino),

Tu, que apenas me restas, tu, agora morres,

Morres a dura morte

$\mathrm{Na}$ carta do baralho em que te enterram viva. ${ }^{42}$

Se a flauta lançada aos «peixes surdos-mudos do man» encerrava a história de Anfion, aqui a voz do rei «ofende os peixes mudos», e nada se encerra:

Que dizer dos serenos monstros gelados, Os quais têm uma voz de sangue sufocando A voz que eles não têm? ${ }^{43}$

Próximo do desfecho do poema de Valéry, o «coro do povo» aclamava Amphion; no poema de Augusto de Campos, é o rei que se dirige ao «povo», como a justificar, enfim, a epígrafe de Hölderlin. Mas o rei tem dificuldades mesmo em apenas ver o «[s]eu povo»:

Povo meu ó meu polvo

Nas cabeças escuras e nos braços amargos.

Onde os teus olhos, onde

Em tanto visgo a areia?

Estremeces os braços, vens de longas águas.

Onde os teus olhos, onde?

Escorreram no visgo a clara substância

Ou a areia os enxuga até as tristes raízes?

Moves a negra massa e negra

Guiam-na os olhos cegos como bocas.

Moves-te em derredor e enquanto dormes

Deixas um rasto sempre o mesmo, negro.

Serão teus estes crânios escuros que parecem

Vivos embora escuros crânios,

Estas bocas sem lábios que ainda vomitam sangue

E devoram devoram outros crânios escuros

Pelas nucas inertes?

${ }^{42} I d .$, p. 12.

${ }^{43} I d$., p. 14. 


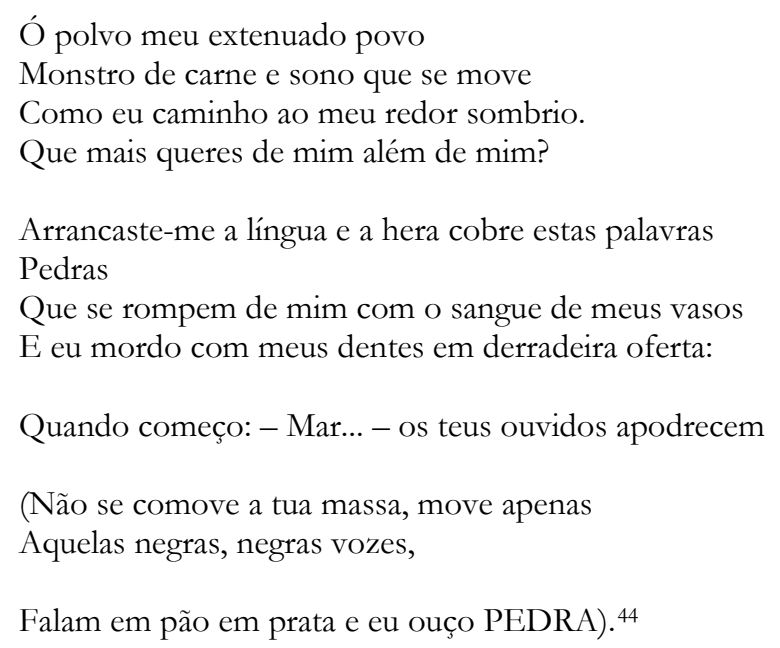

Não parece ser gratuito que, ainda no ano de publicação, 1951, um exemplar do primeiro livro de Augusto de Campos, enviado por seu autor, tenha chegado ao escritório londrino do então cônsul-adjunto Cabral. ${ }^{45}$ São notáveis as recorrências temáticas, imagéticas e mesmo formais entre a «Fábula de Anfion» e «O rei menos o reino», e talvez Augusto de Campos quisesse, com a remessa do livro, antes de tudo reconhecer sua dívida com Cabral. De qualquer modo, afora este episódio registrado pelo biógrafo de Cabral, não há evidências concretas de que Augusto de Campos tenha lido a «Fábula» antes de compor seu poema - não podemos esquecer que a Psicologia da composição com a Fábula de Anfion e Antiode foi impressa numa prensa manual pelo próprio Cabral e que a tiragem da edição foi de pouco mais de cem exemplares. É certo que, num artigo de outubro de 1955, Augusto de Campos, depois de afirmar que, «no Brasil, o primeiro a sentir [os] novos problemas» que estavam na base da poesia concreta foi João Cabral, acrescenta que foi com o livro de 1947 que Cabral «ating[iu] a maturidade expressiva, já prenunciada em $O$ engenheiro». ${ }^{46}$ Porém, à época da publicação do artigo, a «Fábula» já se encontrava nos Poemas reunidos saídos em 1954 pela editora carioca Orfeu, e Augusto de Campos a pode ter lido aí.

No entanto, para além da difícil tarefa de comprovar ou refutar de uma vez por todas o nexo direto entre «O rei menos o reino» e a «Fábula de Anfion», o que fica é a constatação de que em ambos os poemas seus autores mobilizam uma mesma constelação de figuras fundamentais para apresentar posições ético-estéticas convergentes, apesar das inevitáveis diferenças. Como vimos, é comum aos dois poemas, antes de tudo, a imagem de um rei frente a um deserto. E é comum também a ambos o

${ }^{44} I d .$, p. 15.

45 José Castello, João Cabral de Melo Neto. O homem sem alma cit., p. 95.

46 Augusto de Campos, «Poesia concreta» (1955), em Augusto de Campos, Haroldo de Campos e Décio Pignatari, Teoria da poesia concreta. Textos críticos e manifestos 1950-1960, São Paulo: Brasiliense, 1987, p. 40. 
contágio entre paisagem negativa e personagem, assim como entre estes e o poema: a aridez ou esterilidade da terra deixa de ser apenas a situação adversa com que o rei tem de se confrontar e se torna um princípio poético e, antes, ético-estético. Esse posicionamento não estava previsto no poema valéryiano de que Cabral tomou emprestada a figura de Anfion. De onde, então, podemos nos perguntar, João Cabral e Augusto de Campos tiraram essa idéia?

A imagem de um rei que reina sobre um deserto - ou, mais precisamente, sobre uma terra devastada - é um tópos de origem medieval, que apareceu pela primeira vez no Conto do Graal, que o poeta francês Chrétien de Troyes escreveu na década de 1180. Já aí o contágio entre personagem e paisagem é decisivo: a uma terre gaste (uma «terra devastada») corresponde um roi maheigniez [mehaignie] (um «rei ferido» ou «mutilado» - mais literalmente, «machucado», «estragado»). ${ }^{47}$ Este tópos foi retomado pelos diversos autores que reescreveram, nos anos seguintes, a história do cavaleiro Perceval; o tópos apareceria também, com uma interessante transferência do âmbito arturiano para o âmbito grego, no canto XIV do Inferno dantesco (é Creta o paese guasto a que Dante se refere); mas ressurgirá com toda força (por intermédio de um estudo célebre de Jessie L. Weston) somente no século XX, com o principal poema de T. S. Eliot, The Waste Land, no qual o paradigma do contágio ou da contaminação é levado ao extremo, com a esterilidade da terra tornandose um símbolo de uma esterilidade geral identificada por Eliot em seus contemporâneos. ${ }^{48}$ É nesta seqüência que, a meu ver, os poemas de Cabral e de Augusto de Campos também vão, em alguma medida, se encadear. Não se deve estranhar que o que era denúncia da esterilidade em Eliot se torne desejo de esterilidade em Cabral - e, em alguma medida, também em Augusto de Campos. Conforme Edmund Wilson observou com espanto no capítulo sobre Eliot de $O$ castelo de Axel, muitos daqueles poetas que se propuseram dar prosseguimento a The Waste Land converteram a denúncia em apologia do deserto. (Com o sucesso quase imediato de The $W$ aste Land entre os poetas, as imitações logo proliferaram entre os jovens, o que levou Brian Howard a dizer: «Tornou-se um praga tão grande que no momento em que o olho deparava, num poema recentemente chegado, as

${ }^{47}$ Chrétien de Troyes, Perceval ou le Conte du Graal, em CEurres complètes, édition publiée sous la direction de Daniel Poirion, Paris: Gallimard (Bibliothèque de la Pléiade), 1994, p. 774.

48 Jessie L. Weston, From Ritual to Romance (1920), Mineola: Dover, 1997. T. S. ELIOT, «The Waste Land» (1922), em The Complete Poems and Plays: 1909-1950, New York, San Diego and London: Harcourt Brace, 1980, pp. 37-55. 
palavras 'pedra', 'pó' ou 'seco' buscava logo a cestinha de lixo [the waste-paper basket]». ${ }^{49}$ ) Não podemos esquecer também que, a partir de meados da década de 1940, Eliot esteve entre os autores de maior estima entre os jovens poetas brasileiros. Como se sabe, ele ao lado de Valéry, Rilke e Pessoa - era considerado um dos modelos fundamentais por aqueles que se autodenominaram poetas da «Geração de 45», com a qual tanto Cabral quanto os futuros integrantes do grupo da poesia concreta (entre os quais Augusto) foram identificados - se não por um critério crítico, por um critério cronológico.

Quem melhor demonstrou o equívoco desta identificação foi Sérgio Buarque de Holanda, em três artigos publicados no Diário Carioca de maio a junho de 1951 - artigos nos quais, ao lado do nome de Cabral, aparecem os nomes de Haroldo de Campos irmão de Augusto - e de Décio Pignatari como poetas capazes de proceder à «superação efetiva do modernismo» brasileiro, não apenas como «atitude de reação» aos modernistas de 1922 e 1930 (reação a que aspirava a "Geração de 45»), mas como afirmação independente de uma nova poética. ${ }^{50}$ Que esta superação do modernismo estivesse conscientemente em pauta seja na «Fábula de Anfion», seja em «O rei menos o reino», me parece inegável: como evidência, basta frisar a estranheza dos dois poemas se colocados em confronto com os grandes poemas das duas ou três décadas anteriores, seja pelas imagens mobilizadas cuja negatividade extrema contrasta com o imaginário predominantemente positivo ou eufórico do modernismo (ainda que essa positividade e essa euforia devam ser compreendidas de modo dialético, como contrafaces de uma negatividade de base ${ }^{51}$ ), seja pelo próprio manejo da linguagem e da forma, que foge da «doxa lingüística» modernista do coloquialismo. ${ }^{52}$

É interessante notar que a «superação efetiva do modernismo», que se verifica exemplarmente nos dois poemas aqui examinados, resulta menos de uma radicalização do moderno do que uma interpelação e questionamento do moderno pelo antigo (na figura de Anfion) e, sobretudo, pelo medieval (na imagem da terra devastada associada à do rei). Passa-se, na «Fábula de Anfion» como em «O rei menos o reino», do dilema da querela histórica previsível (modernidade contra não-modernidade) a uma intrincada dialética (modernidade com não-modernidade), em que anacronismos e sobrevivências revelam-se

49 Brian Howard, New Statesman, 8 nov. 1930, apud Peter ACKroyd, T. S. Eliot, London: Penguin, 1984, p. 128.

50 Sérgio Buarque de Holanda, «A difícil alvorada», em O espírito e a letra. Estudos de crítica literária, org., introd. e notas Antonio Arnoni Prado, 2 v., São Paulo: Companhia das Letras, 1996, v. 2, pp. 389-392 (citação à p. 392). Cf. também «Rito de outono» e «Ritmo e compasso», idem, respectivamente pp. 393-396 e 397-401.

51 Cf. Eduardo STERZI, A prova dos nove. Alguma poesia moderna e a tarefa da alegria, São Paulo: Lumme, 2008.

52 Abel Barros Baptista e Osvaldo Manuel Silvestre, «Apresentação: Conversa interessantíssima», em Seria uma rima, não seria uma solução. A poesia modernista, org. Abel Barros Baptista e Osvaldo Manuel Silvestre, Lisboa: Cotovia, 2005, p. 57. 
tão essenciais à arte, mesmo em sua fase «moderna», quanto os impulsos rumo ao novo e ao desconhecido. Esta irrupção da medievalidade em plena modernidade (ou pósmodernidade) não é difícil de ser compreendida. A Idade Média, para os modernos, talvez seja menos uma época em sentido estrito (daí a dificuldade em determinar os seus limites: quando começa? quando termina?) que uma figura de pensamento por meio da qual buscamos lidar com o emaranhado de linhas contínuas e descontínuas de que se tece o intervalo entre a Antigüidade e a Modernidade. «A Idade Média não existe», proclamou o historiador Christian Amalvi. ${ }^{53}$ Desde Petrarca e os humanistas italianos do século XIV, que foram os primeiros a falar, com intenção pejorativa, em medium tempus ou media tempora, a Idade Média vem sendo a grande mediação histórica através da qual se vem dialetizando o dilema entre Antigüidade e Modernidade. Suas imagens, quando aparecem em textos ditos «modernos», têm sobretudo a função de inquietar a história - antes de tudo, a história da literatura e da cultura, que então deixa aflorar sua estranheza e sua complexidade constitutivas, mas também a história em geral. Afinal, se como observou Paul de Man, «a modernidade de um período literário» pode ser definida como «a maneira como ele descobre a impossibilidade de ser moderno», também a modernidade tout court está freqüentemente condenada a trocar suas ilusões de uma cidade ideal, «nuvem civil sonhada», pela lucidez terrível da visão de um «deserto» ou de uma «terra devastada». Se o recurso ao mito antigo tinha por objetivo dar corpo às idéias, como vimos com Valéry, talvez possamos dizer que o recurso ao mito medieval tem por objetivo desvelar os fantasmas que sempre acompanham tais corpos. Isto é, não ocultar a destruição que subjaz a estes poemas, especificamente, mas também a todos os demais «documentos da cultura». ${ }^{54}$

Será preciso recordar as datas de composição e publicação da «Fábula de Anfion»e de «O rei menos o reino» para que os vínculos entre poesia e história aí estabelecidos sejam levados em consideração? Se Drummond e Murilo Mendes foram, dentre os escritores brasileiros, aqueles que melhor traduziram poeticamente a Segunda Grande Guerra enquanto esta estava em curso, talvez Cabral e Augusto de Campos sejam, com seus poemas desérticos, nossos grandes poetas do imediato Pós-Guerra, com tudo que isso comportou de reconhecimento da catástrofe contemporânea. Podemos imaginar o próprio Cabral diante das imagens de devastação que então corriam mundo - as ruínas

\footnotetext{
53 Christian Amalvi, «Idade Média», trad. José Carlos Estêvão, em Jacques Le Goff e Jean-Claude Schmitt (org.), Dicionário temático do Ocidente medieval, São Paulo: Imprensa Oficial; Bauru: EDUSC, 2002, p. 537.

${ }^{54}$ Cf. Walter Benjamin, «Sobre o conceito de história», trad. Jeanne Marie Gagnebin e Marcos Lutz Müller, em Michael LÖWY, Walter Benjamin: aviso de incêndio. Uma leitura das teses "Sobre o conceito de história", trad. Wanda Nogueira Caldeira Brant, São Paulo: Boitempo, 2005, p. 70.
} 
das cidades bombardeadas, os escombros de Hiroshima e Nagasaki, os cadáveres desenterrados nos campos de extermínio, os sobreviventes destruídos física e psicologicamente - e formulando-se uma pergunta que não seria, em substância, muito diversa daquele de seu personagem:

Onde a cidade

volante, a nuvem

civil sonhada? 55

Ou podemos pensar no próprio Augusto de Campos descobrindo, nas mesmas imagens, circunstâncias semelhantes àquela que registraria em seu poema: um «duro reino» em que o rei (rei sem «vassalos», que pode ser, pois, uma figuração do homem qualquer) «à falta de reino pisa o próprio corpo». ${ }^{56}$

Essa leitura, contudo, pode ser levada ainda a outro patamar. Recentemente, Giorgio Agamben trouxe à tona o «mitologema genuinamente político» oculto no mito literário da terra devastada. A figura do roi mehaignié é interpretada, em O Reino e a Glória, como «o paradigma de uma soberania dividida e impotente»:

\begin{abstract}
Mesmo sem perder nada da sua legitimidade e da sua sacralidade, o rei foi, de fato, por algum motivo, separado dos seus poderes e das suas atividades e reduzido à impotência. [...] O roi mehaignié contém, então, uma espécie de prefiguração do soberano moderno, que "reina, mas não governa" e, neste sentido, a lenda poderia ter um sentido que nos concerne mais de perto. ${ }^{57}$
\end{abstract}

O que aí se coloca - e, em alguma medida, volta a se colocar nos poemas de João Cabral e de Augusto de Campos - é nada menos que a dissociação entre Reino e Governo, entre auctoritas e potestas, entre potência absoluta e potência ordenada, entre política e economia (ou política e administração), dissociação tão definidora de nossos dias:

\begin{abstract}
O poder soberano se articula constitutivamente segundo dois planos ou aspectos ou polaridades: é, ao mesmo tempo, dignitas e administratio, Reino e Governo. O soberano é constitutivamente mehaignié, no sentido que a sua dignidade se mede à possibilidade da sua inutilidade e ineficácia, numa correlação em que o rex inutilis legitima a administração efetiva que sempre já separou de si e que, todavia, continua formalmente a pertencer-lhe. ${ }^{58}$
\end{abstract}

\footnotetext{
55 João Cabral de Melo Neto, «Fábula de Anfion» cit., p. 92. Seria interessante reler a figura da cidade neste poema de Cabral a partir da proposição de Giorgio Agamben de que, na modernidade, o campo de concentração e de extermínio substituiu a cidade como «paradigma biopolítico do ocidente» (Homo sacer. Il potere sourano e la nuda vita [1995], Torino: Einaudi, 2005, p. 202); na figuração de uma «cidade volante»onírica, fugidia, frágil - talvez Cabral já estivesse anotando precocemente, antecipando-se ao filósofo, essa troca de paradigma.

56 Augusto de Campos, «O rei menos o reino» cit., p. 12.

${ }^{57}$ Giorgio Agamben, Il Regno e la Gloria. Per una genealogia teologica dell'economia e del governo (Homo sacer, II, 2), Vicenza: Neri Pozza, 2007, p. 84.

58 Id., p. 114.
} 
Max von Seydel, mestre do direito público lembrado por Carl Schmitt e por Agamben, indagou certa feita o que permaneceria do reinar se suprimíssemos o governar; Agamben responde a esta questão com uma formulação ao mesmo tempo vertiginosa e cristalina: «O Reino é o resto que se põe como o todo que se subtrai infinitamente a si mesmo». ${ }^{59}$ Podemos nos perguntar, então, se o rei sem reino - mas com deserto - de Augusto de Campos, assim como Anfion, saudoso do deserto, lamentando-se diante da cidade fundada e, então, lançando voluntariamente sua flauta aos «peixes surdos-mudos do man», não são figurações daquele Reino que, segundo Agamben, emergiria do Dia do Juízo: um Reino «radicalmente desprovido de governo», que é a meta de toda a verdadeira política. ${ }^{60}$

Só se compreende plenamente a reapropriação da figura do rei frente a um deserto por Cabral e Augusto de Campos ao se perceber toda a complexidade e toda a ambivalência desta imagem tal como ela ressurge neste momento histórico específico. Trata-se, afinal, de uma autêntica «imagem dialética», para falarmos como Walter Benjamin $^{61}$ : uma imagem a um só tempo medieval e moderna, irredutível seja a seu momento de proveniência (a Idade Média), seja a seu momento de recorrência (a Modernidade); mas também uma imagem de denúncia (o deserto como figuração do mundo devastado do pós-guerra) ao mesmo tempo que uma imagem de desejo, e desejo político tanto quanto poético (o «rei menos o reino» como figuração de um «Reino» dissociado de qualquer «Governo», assim como o deserto como figuração do princípio ético-estético que norteia o poema).

No mesmo livro, O Reino e a Glória, em que põe a nu o sentido político do mito do roi mehaignié, Giorgio Agamben oferece importantes considerações acerca da forma poética do bino como «radical desativação da linguagem significante». ${ }^{62}$ Agamben encontra justamente em Mallarmé - autor fundamental para Valéry, para Cabral, para Augusto de Campos - o exemplo extremo do «isolamento hínico da palavra». ${ }^{63} \mathrm{O}$ poema aparece aí em Mallarmé, mas também em seus sequazes - como modelo daquela inoperância (inoperosità) que é, segundo Agamben, a dimensão mais própria do homem:

\footnotetext{
${ }^{59}$ Id., ibid.

${ }^{60} I d .$, p. 177.

61 Walter Benjamin propõe a noção de imagem dialética em vários fragmentos da seção N («Teoria do conhecimento, teoria do progresso») de seu trabalho sobre as Passagens, trad. Irene Aron (alemão) e Cleonice Paes Barreto Mourão (francês), org. e posf. Willi Bolle e Olgária Chain Féres Matos, Belo Horizonte: Editora UFMG; São Paulo: Imprensa Oficial, 2006, pp. 499-530.

${ }^{62}$ Giorgio Agamben, Il Regno e la Gloria. Per una genealogia teologica dell'economia e del governo cit., p. 260.

${ }^{63}$ Id., p. 207.
} 
[...] a práxis propriamente humana é um sabatismo, que, tornando inoperantes as funções específicas do vivente, o abre em possibilidades. Contemplação e inoperância são, neste sentido, os operadores metafísicos da antropogênese, que, liberando o vivente homem do seu destino biológico ou social, o destinam [assegnano] àquela indefinível dimensão que estamos habituados a chamar política. O político [é] a dimensão que a inoperância da contemplação, desativando as práxis lingüísticas e corpóreas, materiais e imateriais, incessantemente abre e atribui ao vivente. [...] Um modelo desta operação que consiste em tornar inoperantes todas as obras humanas e divinas é o poema. Pois que a poesia é precisamente aquela operação lingüística que torna inoperante a língua - ou, nos termos de Spinoza, o ponto em que a língua, que desativou as suas funções comunicativas e informativas, repousa em si mesma, contempla a sua potência de dizer e se abre, deste modo, a um novo, possível uso. [...] Aquilo que a poesia realiza para a potência de dizer, a política e a filosofia devem realizar para a potência de agir. Tornando inoperantes as operações econômicas e biológicas, essas mostram o que pode o corpo humano, o abrem a um novo, possível uso. ${ }^{64}$

Se por um lado o substrato hínico de procedência mallarmeana talvez possa explicar certas indeterminações da «Fábula de Anfion»e de «O rei menos o reino», a permanente esquiva de ambos os poemas a uma significação estabilizada de uma vez por todas (característica do hino é propriamente esta esquiva) ${ }^{65}$, por outro a avaliação agambeniana do poema como modelo de inoperância nos permite compreender a relevância que a poesia sobre a própria poesia sempre teve nas obras de João Cabral e Augusto de Campos. O que poderia parecer sinal de solipsismo poético talvez seja antes a maneira encontrada pelos poetas de repensar nos termos específicos de sua própria atividade nada menos que o núcleo secreto de toda a vida política.

[Publicação original: «O reino e o deserto. A inquietante medievalidade do moderno», Letterature d'America, Roma, 125 (2010), pp. 61-87.]

${ }^{64} I d$. , pp. $274-275$.

${ }^{65} \mathrm{E}$ os poemas de João Cabral e Augusto de Campos aqui em questão, se não em seu todo, pelo menos em alguns de seus momentos, apresentam inequívocas tendências à configuração hínica, isto é, à conjugação de celebração e desativação da semântica. Isto fica mais claro nos trechos de ambos que começam com interjeições: «Ó acaso», na «Fábula de Anfion» (cit. pp. 89-90), e « Povo meu ó meu polvo», em «O rei menos o reino» (cit. p. 15). 